УДК 658.567

\title{
ДОСЛІДЖЕННЯ КІЛЬКОСТІ ТЕПЛОТИ, ЩО ВИДІЛЯЄТЬСЯ ПРИ СПАЛЮВАННІ ЗМІШАНИХ ТВЕРДИХ ПОБУТОВИХ ВІДХОДІВ М. КИЄВА
}

Сігал О.І. ${ }^{1}$, канд. техн. наук, Крикун С.С. ${ }^{2}$, Павлюк Н.Ю. ${ }^{1}$, канд. техн. наук, Сатін I.B. ${ }^{3}$, канд. техн. наук, Плашихін С.B. ${ }^{1}$, канд. техн. наук, Кіржнер Д.А. ${ }^{1}$, Семенюк М.В. ${ }^{1}$, Каменьков Г.Б. ${ }^{1}$

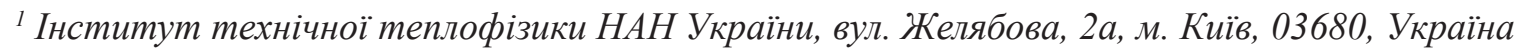

${ }^{2}$ Філіал «Завод “Енергія”» ПАТ «Київенерго», вул. Колекторна, 46, м. Київ, 02000, Украйна

${ }_{3}^{3}$ Державне підприємство «Науково-дослідний та конструкторсько-технологічний інститут міського господарства», вул. Митрополита Василя Липківського, 35, м. Київ, 03035, Україна

Проаналізовано теплотворну здатність твердих побутових відходів різних країн, розраховану на підставі елементного складу компонентів ТПВ. Наведено результати експериментальних досліджень кількості теплоти, що виділяється при спалюванні змішаних ТПВ м. Києва. Результати роботи використані на сміттеспалювальному заводі «Енергія» ПАТ «Київенерго».
Проанализирована теплотворная способность твердых бытовых отходов разных стран, рассчитанная на основе элементного состава компонентов ТБО. Приведены результаты экспериментальных исследований количества теплоты, которое выделяется при сжигании смешанных ТБО г. Киева. Результаты работы использованы на заводе «Энергия» ПАО «Киевэнерго».
The calorific value of the municipal solid waste in different countries was calculated on the basis of elementary composition of the municipal solid waste.

The results of the experimental research on the amount of heat produced during the combustion of mixed municipal solid waste in Kiev city are given.

The results of the research were used at the "Energy" plant of PJSC "Kyivenergo".

Бібл. 13, табл. 5, рис. 4.

Ключові слова: тверді побутові відходи, спалювання ТПВ, нижча теплотворна здатність, кількість теплоти, вологість.

Сучасний тренд розвитку світової енергетики спрямований на скорочення споживання викопного палива, зокрема заміщення його альтернативними джерелами енергіі. Тверді побутові відходи (ТПВ) визначені в Директиві 2008/98/СС «Про відходи» та в проекті Національної стратегії поводження 3 відходами в Україні як вторинний матеріальний та енергетичний антропогенний ресурс. Суттєвою перевагою використання ТПВ в якості джерела енергії є постійне зростання його кількості та зручне розташування - в населених пунктах, поруч зі споживачами енергії.

Провідні країни світу вже багато років розглядають ТПВ як постійно зростаюче альтернативне джерело енергії, здатне в крупних містах з населенням більш, ніж $500 \ldots 600$ тис. мешканців частково замістити природний газ при виробництві теплової і електричної енергії шля- хом впровадження ТЕЦ-на-ТПВ. Використання ТПВ для виробництва енергії активно розвивається в багатьох країнах світу. Наприклад, в 2014 р. в СС працювало 483 ТЕЦ-на-ТПВ, на яких було спалено 88,5 млн. т ТПВ.

Доцільність впровадження ТЕЦ-на-ТПВ в окремому населеному пункті залежить від морфології ТПВ, теплотворної здатності компонентів та вологості змішаних ТПВ, тобто кінцевої кількості теплоти, яку можна отримати при їх спалюванні.

Визначенню теплотворної здатності ТПВ присвячено багато досліджень. Узагальнені значення теплотворної здатності ТПВ різних країн світу представлено в табл. 1 [1].

Спостерігається пряма залежність теплотворної здатності ТПВ країни від рівня купівельної спроможності iii населення [2].

Табл. 1. Теплотворна здатність ТПВ країн світу

\begin{tabular}{|c|c|c|c|}
\hline Країни & $\begin{array}{c}\text { Теплотворна здатність } \\
\text { ТПВ, ккал/кг }\end{array}$ & Країни & $\begin{array}{c}\text { Теплотворна здатність } \\
\text { ТПВ, ккал/кг }\end{array}$ \\
\hline Китай & $800 \ldots 1200$ & Японія & $1200 \ldots .2500$ \\
\hline Корея & $1000 \ldots 1500$ & Європа (без Швейцарії) & $1800 \ldots 2500$ \\
\hline Бразилія & $1000 \ldots 1500$ & США & $2200 \ldots 3250$ \\
\hline Тайвань & $1000 \ldots 1800$ & Швейцарія & $2200 \ldots 3600$ \\
\hline Сінгапур & $1000 \ldots 2000$ & & \\
\hline
\end{tabular}


Зазвичай нижча теплотворна здатність ТПВ визначається відповідно до морфологічного складу відходів, елементного складу окремих компонентів ТПВ та їх вологості. Теплотворна здатність кожного елементу визначається в калориметричній бомбі, теплота згоряння розраховується за відомою формулою Менделєєва [3]. Деякі дослідники вивели власні формули визначення теплотворної здатності кожного еле- мента ТПВ [4,5].

В табл. 2 показані результати розрахунків теплотворної здатності компонентів ТПВ, проведених організаціями провідних країн світу: Департаментом навколишнього середовища, продовольства і сільського господарства Великобританії (Defra) [6], Світовим Банком (WB) [7] та Міжнародною асоціацією 3 твердих відходів (ISWA) [8].

Табл. 2. Морфологія та нижча теплотворна здатність компонентів ТПВ за дослідженнями фахівців організацій провідних країн світу

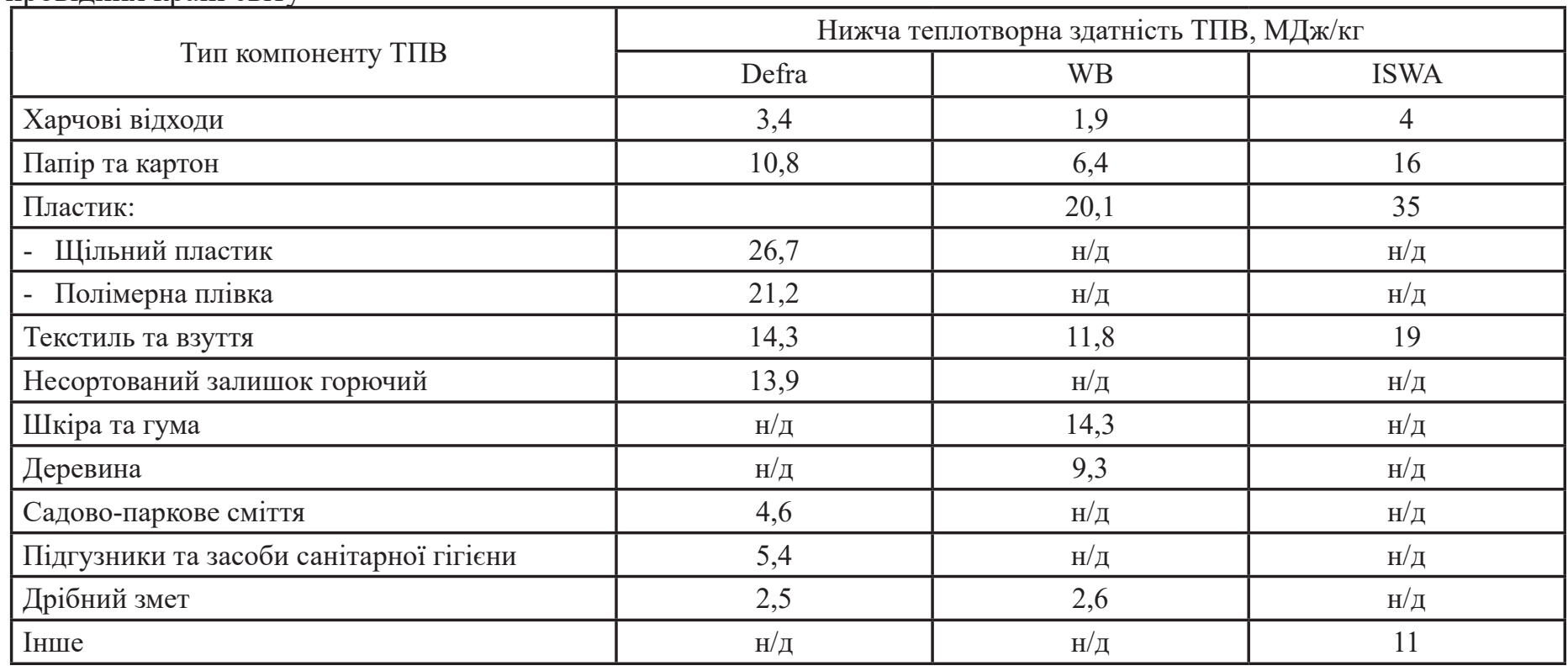

Табл. 3. Нижча теплотворна здатність компонентів ТПВ за дослідженнями фахівців України та країн СНД

\begin{tabular}{|c|c|c|c|c|c|c|c|}
\hline \multirow[b]{2}{*}{$\begin{array}{c}\text { Тип } \\
\text { компоненту } \\
\text { ТПВ }\end{array}$} & \multicolumn{7}{|c|}{ Нижча теплотворна здатність, МДж/кг } \\
\hline & $\begin{array}{c}\text { Дослідження } \\
\text { Україна }^{1} \\
{[9]}\end{array}$ & $\begin{array}{c}\text { Дослідження } \\
\text { Україна }^{1} \\
{[10]}\end{array}$ & $\begin{array}{c}\text { Дослідження } \\
\text { Україна }^{1} \\
{[11]}\end{array}$ & $\begin{array}{c}\text { Дослідження } \\
\text { за формулою } \\
\text { Менделєєва } \\
\text { (РФ) } \\
{[12]}\end{array}$ & $\begin{array}{c}\text { Дослідження } \\
\text { ТПВ } \\
\text { м. Москва за } \\
\text { методикою } \\
\text { ВАТ «ВТІ» } \\
\text { (РФ) [12] }\end{array}$ & $\begin{array}{c}\text { Дослідження } \\
\text { АКГ } \\
\text { (РФ) [3] }\end{array}$ & $\begin{array}{c}\text { Дослідження } \\
\text { ТПВ } \\
\text { м. Астана } \\
\text { (Казахстан) } \\
\text { [13] }\end{array}$ \\
\hline $\begin{array}{l}\text { Харчові } \\
\text { відходи }\end{array}$ & $3,1 \ldots 3,8$ & 3,5 & $3,5 \ldots 4,0$ & 6,2 & 5,3 & 3,4 & 3,3 \\
\hline $\begin{array}{l}\text { Папір та } \\
\text { картон }\end{array}$ & $7,5 \ldots 11,5$ & 9,5 & $14,0 \ldots 15,0$ & 14,2 & 12,9 & 9,5 & 9,9 \\
\hline $\begin{array}{l}\text { Пластмаса, } \\
\text { полімери }\end{array}$ & $17 \ldots 46,0$ & 24,4 & $27,0 \ldots 28,0$ & 27,2 & 26,3 & 24,4 & 24,4 \\
\hline Текстиль & $12,1 \ldots 14,2$ & 15,0 & $14,0 \ldots 15,0$ & 19,1 & 18,7 & 15,7 & 15,7 \\
\hline $\begin{array}{l}\text { Відсів } \\
\text { менш, } \\
\text { ніж } 16 \text { мм }\end{array}$ & н/д & 3,1 & н/д & $\mathrm{H} /$ д & 7,04 & 4,6 & 4,6 \\
\hline Зола, шлак & $\mathrm{H} /$ Д & $\mathrm{H} /$ д & $\mathrm{H} / д$ & $\mathrm{H} /$ Д & $\mathrm{H} /$ д & 8,7 & $\mathrm{H} /$ Д \\
\hline Інше & н/д & н/д & н/д & н/д & $\mathrm{H} /$ д & 18,1 & $\mathrm{H} /$ д \\
\hline
\end{tabular}

${ }^{1}$ дані до 2014 року 
Результати розрахунків теплотворної здатності ТПВ, проведених в Харківському національному університеті міського господарства ім. О.М. Бекетова [9], Миколаївському Національному університеті кораблебудування ім. адмірала Макарова [10], Пермському національному дослідницькому політехнічному університеті (РФ) [11, 12], ВАТ «Всеросійський теплотехнічний інститут» (ВАТ «ВТІ») (РФ) [11], Академії комунального господарства ім. К.Д. Памфилова (АКГ) (РФ) [3], та Свразійському національному університеті ім. Л.М. Гумільова (Казахстан) [13] представлені в табл. 3.

Відповідно до інформації, наведеної в таблицях 2-3, класифікація ТПВ провідних країн світу значно детальніша, ніж в країнах СНД.

Стандартне відхилення нижчої теплотворної здатності компонентів ТПВ (за винятком пластма- си, полімерів) за дослідженнями фахівців України при мінімальних значеннях становить 7,6 \% (рис. 1, a), а при максимальних значеннях - 2,5 \% (рис. 1, б). Аналіз стандартного відхилення $\mathrm{Q}_{\mathrm{H}}^{\mathrm{p}}$ за дослідженнями фахівців України показує близьку збіжність їх результатів, що $\epsilon$ свідченням коректності отриманих результатів. Врахування теплотворної здатності пластмаси призводить до підвищення мінімального значення стандартного відхилення до 12,8 \% (рис. $1, a)$, а максимального - до 17,8 \%. Ця похибка $\epsilon$ наслідком явної невідповідності аналізуємих матеріалів через величезне різноманіття пластмасових/ полімерних виробів, що підтверджує необхідність запровадження в Україні методики детальної класифікації компонентів ТПВ для подальшого аналізу, та відходу від практики їх узагальнення.

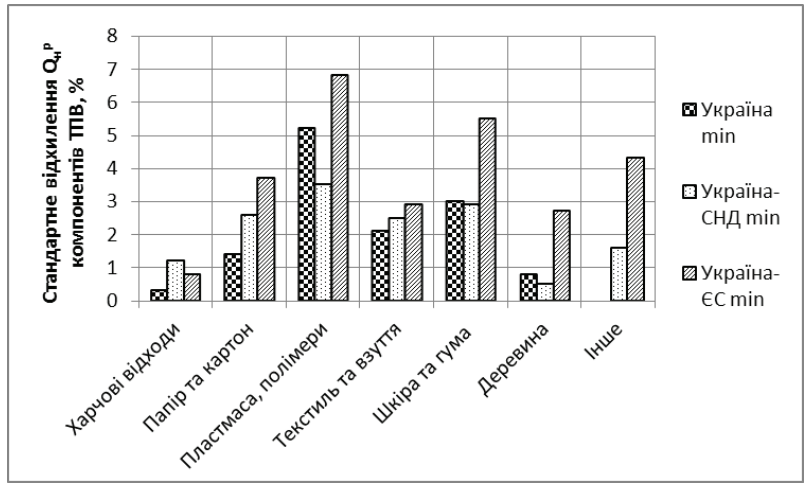

a) $\min$ - значення

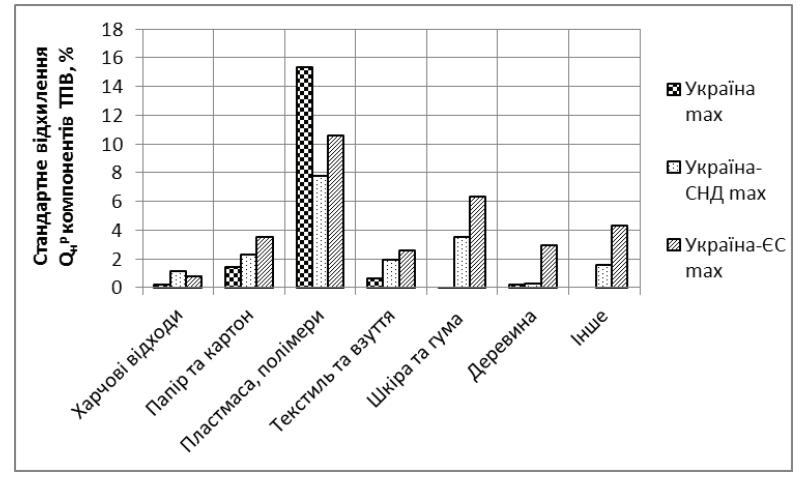

б) $\max$ - значення

Рис. 1. Стандартне відхилення нижчої теплотворної здатності компонентів ТПВ за дослідженнями фахівців Украӥни, та в порівнянні з дослідженнями фахівців крайн СНД та СС.

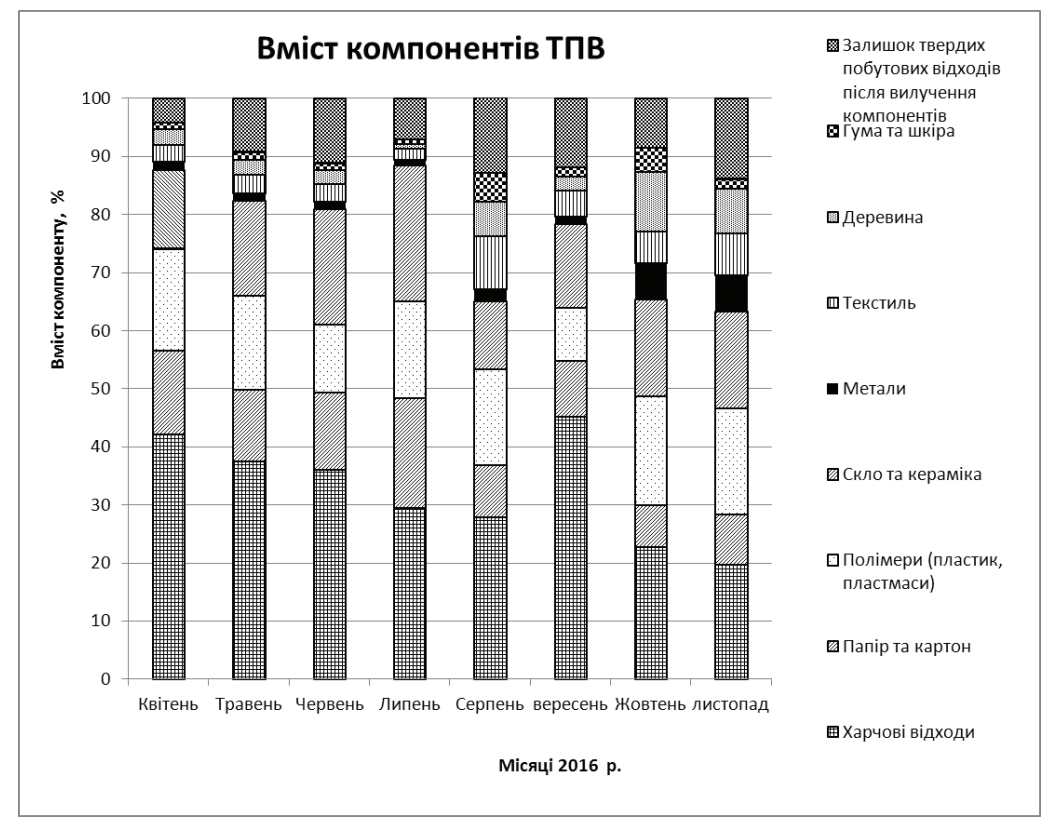

Рис. 2. Усереднений за місяцями склад ТПВ. 
Як свідчать дані рис. 1, мінімальне стандартне відхилення нижчої теплотворної здатності компонентів ТПВ за дослідженнями фахівців країн СНД (14,8 \%) відрізняється від результатів фахівців України майже в 2 рази, а максимальне $(18,5 \%)$ - приблизно в 7 разів; мінімальне стандартне відхилення за дослідженнями фахівців країн СС і України (26,7 \%) відрізняється в 3,5 рази, а максимальне (31 \%) - в 12 разів, що пояснюється відмінністю морфології ТПВ між країнами, тобто їх ототожнення не є коректним.

В Києві працює сміттєспалювальний завод «Енергія» ПАТ «Київенерго» (далі «Завод»), на якому спалюються змішані ТПВ. При спалюванні ТПВ виробляється теплова енергія, яка використовується для теплозабезпечення житлового району «Позняки» м. Києва. 3 метою визначення перспектив щодо можливості і доцільності розширення Заводу та переобладнання його в ТЕЦ-на-ТПВ була виконана ця робота.

Щомісячний морфологічний склад та вологість ТПВ визначалися експериментально.

Усереднений за місяцями року склад ТПВ представлений на рис. 2.

Аналіз вмісту компонентів (за масою) в складі

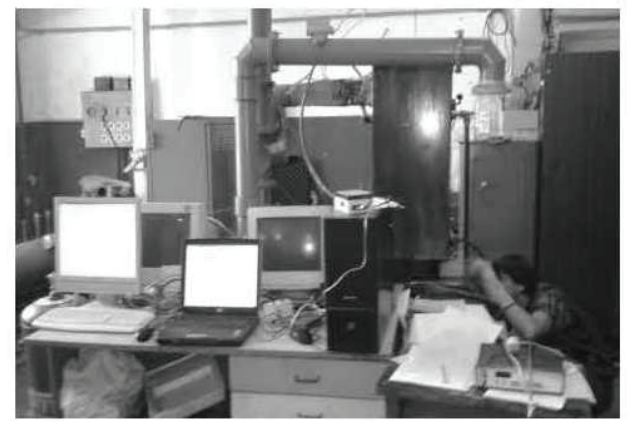

Рис. 3. Експериментальний стенд для дослідження кількості теплоти, щцо виділялась при спалюванні змішаних ТПВ. змішаних ТПВ та вологості показав їх суттєву залежність від місяцю та сезону збору.

На основі результатів дослідження морфології та вологості ТПВ, авторами проводились експериментальні дослідження визначення кількості теплоти, що виділяється при спалюванні змішаних твердих побутових відходів, які поступають на Завод, усереднених за сезонами року. Дослідження проводились при вологості повітряно-сухого стану ТПВ, а також при вологості, 3 якою ТПВ вивантажувались зі сміттєвозів до завантажувального бункеру Заводу.

Експерименти проводились на лабораторному стенді, до складу якого входив блок подачі газу для підсвічування (пропан-бутанова суміш), водогрійний котел потужністю 12,5 кВт, спеціально підготовлений для спалювання змішаних ТПВ, система відводу продуктів згоряння та контрольно-вимірювальне обладнання (рис. 3).

3 метою наближення процесу спалювання наважки ТПВ до умов спалювання ТПВ на Заводі, де сміттєспалювальні котли «Дукла» працюють в безперервному режимі, проводився попередній розігрів топки котла. Контрольним параметром стабілізації теплового режиму топки була стабілізація температури води на виході $з$ охолоджувального контуру. Кількість води на вході і виході охолоджувального контуру котла-калориметра вимірювалась ультразвуковим лічильником теплоти Sharky 775 DN 20 Qn 2,5 (поріг чутливості 4 л/год).

Після стабілізації теплового режиму топки, подача газу для розігріву котла відключалась і на колосникову решітку завантажувалась підготовлена наважка ТПВ.

Наважка змішаних ТПВ моделювалась відповідно до усередненого за сезонами року морфологічного складу ТПВ, згідно даних щодо щомісячного морфологічного складу та вологості ТПВ м. Києва. Узагальнені компоненти ТПВ моделювались сумішшю подібних компонентів. Модельні компоненти наважки ТПВ представлені в табл. 4.

Табл. 4. Модельні компоненти наважки ТПВ

\begin{tabular}{|c|c|l|}
\hline № & $\begin{array}{c}\text { Найменування } \\
\text { компонентів ТПВ }\end{array}$ & \multicolumn{1}{|c|}{ Моделювання компонентів наважки ТПВ } \\
\hline 1. & Харчові відходи & овочеві та фруктові очистки (картопля, морква, цибуля, яблука) \\
\hline 2. & Папір та картон & шматки офісного паперу, періодичних газет, картону \\
\hline 3. & Полімери (пластик, пластмаси) & ПЕТ-пляшки, одноразові поліетиленові пакети, дитячі іграшки \\
\hline 4. & Скло та кераміка & скло скляних пляшок, черепки керамічних виробів \\
\hline 5. & Метали & проволока сталева та мідна, металеві кульки тощо \\
\hline 6. & Текстиль & х/б та шерстяне ганчір'я \\
\hline 7. & Деревина & гілки дерев (сосна, верба, тополя) \\
\hline 8. & Гума та шкіра & $\begin{array}{l}\text { гумові кульки, обрізки гумово-шкіряних виробів (взуття, паски, } \\
\text { гаманці, сумки тощо) }\end{array}$ \\
\hline 9. & $\begin{array}{l}\text { Залишок твердих побутових } \\
\text { відходів після вилучення компонентів }\end{array}$ & дрібне будівельне сміття, каміння, вуличний змет тощо. \\
\hline
\end{tabular}


Наважка ТПВ подрібнювалась та, 3 метою забезпечення ㄲi контрольованої вологості, висушувалась у сушарці (муфельній пічці) до повного видалення незв'язаної вологи. Готовність наважки до спалювання визначалась шляхом зважування на електронних лабораторних вагах Vinzer (точність приладу - 1 г) до отримання незмінної ваги.

Волога, відповідно до заданої вологості ТПВ, додавалась шляхом розміщення ємності з водою в зоні випаровування. Наважка завантажувалась до топки котла i спалювалась 3 підсвічуванням горючим газом (пропан-бутановою сумішшю) або без нього. Витрати газу вимірювались газовим мембранним лічильником Gross MGM-UA G4 (поріг чутливості - 0,003 м³/год). Якщо при завантаженні до розігрітої топки наважки змішаних ТПВ та розпалюванні їі газовим факелом відбувалось загоряння наважки, газ для підсвічування не використовувався.

При використанні газу як палива для підсвічування, зумовлена його спалюванням кількість теплоти віднімалась від отриманої в експерименті сумарної кількості теплоти. Теплотворна здатність підсвічувального газу визначалась в Інституті газу НАН України на газовому хроматографі Agilent $6890 \mathrm{~N}$.

В ході досліджень вимірювались витрата та температура води на вході і виході охолоджувального контуру котла, а також параметри газів, що відходять (витрата, температура, та їх склад). Температура в котлі та в газоході вимірювалась безперервно термоелектричними перетворювачами ТХА-1489 (хромель-алюмелеві термопари) 3 мікропроцесорним модулем реєстрації сигналів «Triton 6004TC» за допомогою програмного забезпечення «Data Recorder-T6004 ts».

Процес спалювання наважки ТПВ тривав до згасання ТПВ та повного охолодження топки, про що свідчило тотожність температури води на вході і виході котла-калориметра $\mathrm{t}_{\text {вх1 }}=\mathrm{t}_{\text {вих } 2}$.

Після зак1нчення експерименту вимірювалася тем- пература та вага шлаку. Вага шлаку вимірювалась електронними лабораторними вагами A500 фірми AXIS (точність приладу 0,01 г).

3 метою визначення втрат теплоти ТПВ від механічного недопалу проводилось термічне допалювання шлаку в муфельній печі для забезпечення повного вигоряння органічних складових. Процес відбувався при температурі біля $800{ }^{\circ} \mathrm{C}$ до сталої ваги зольного залишку.

Охолоджений зольний залишок зважувався на електронних лабораторних вагах.

За різницею ваги шлаку до термічної обробки та ваги зольного залишку після термообробки (спікання) в муфельній печі визначався механічний недопал при спалюванні наважки ТПВ, який складав 5...7\%.

Зольність наважки ТПВ визначалась як відношення ваги зольного залишку до ваги наважки.

На основі отриманих результатів за розробленим алгоритмом розраховувалась кількість теплоти, що утворювалась при згорянні наважки ТПВ, а також зольність.

Експериментальні дослідження спалювання підготовлених наважок ТПВ заданого морфологічного складу проводились у повітряно-сухому стані наважки, та при вологості, з якою ТПВ потрапляють на Завод. Результати досліджень представлені в табл. 5.

Дані табл. 5 наглядно показують негативний вплив вологи на кінцеву кількість теплоти, яку можна отримати при їх спалюванні.

Доведена неможливість самостійного горіння наважок ТПВ при вологості, 3 якою ТПВ потрапляють зі сміттєвозів до Заводу, що вказує на необхідність їх підсушування перед спалюванням.

Усереднена за три сезони 2016 р. експериментально визначена кількість теплоти, що виділилась при спалюванні моделі наважки ТПВ м. Києва в залежності від їі вологості відповідає даним інших авторів щодо теплотворної здатності, розрахованої за теплотворною здатністю окремих компонентів (рис. 4) [9, 10].

Табл. 5. Зведені результати досліджень кількості теплоти, що виділилась при спалюванні наважки ТПВ

\begin{tabular}{|c|c|}
\hline $\begin{array}{l}\text { Вологість } \\
\text { наважки ТПВ, } \\
\text { \% }\end{array}$ & $\begin{array}{c}\text { Кількість теплоти, що виділилась } \\
\text { при спалюванні наважки ТПВ, } \\
\text { ккал/кг }\end{array}$ \\
\hline$W$ & $Q_{\Sigma}$ \\
\hline \multicolumn{2}{|c|}{ у весняний сезон } \\
\hline 33,6 & $1620 \ldots 1688$ \\
\hline 58,3 & $1017 \ldots 1060$ \\
\hline \multicolumn{2}{|c|}{ у літній сезон } \\
\hline 28,6 & $1695 \ldots 1720$ \\
\hline 57,4 & $1026 \ldots 1041$ \\
\hline \multicolumn{2}{|c|}{ в осінній сезон } \\
\hline 27,4 & $1745 \ldots 1774$ \\
\hline 67,3 & $786 \ldots 799$ \\
\hline
\end{tabular}




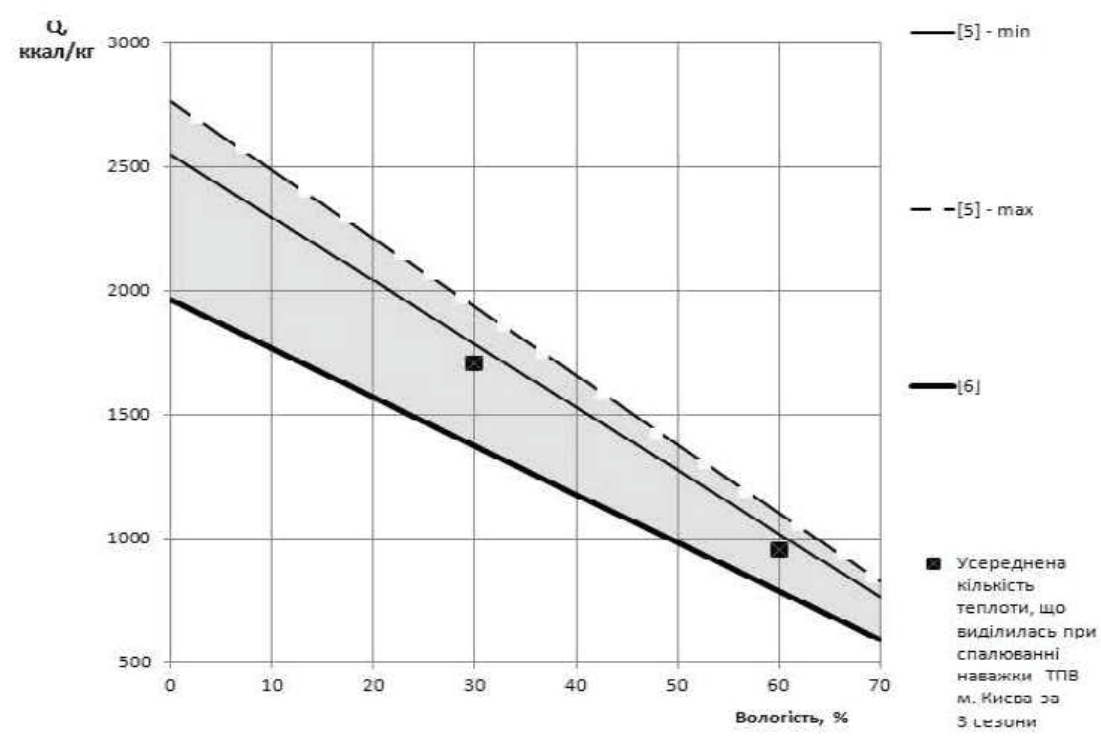

\section{Рис. 4. Відповідність усередненої теплотворної здатності ТПВ м. Києва в залежності від вологості наявним літературним даним.}

\section{Висновки}

1. Для якісного аналізу морфології ТПВ необхідно запровадити практику детальної класифікації компонентів ТПВ з подальшим аналізом їх теплотворної здатності, вологості та зольності.

2. Підвищення вологості ТПВ 3 вологості повітряно-сухого стану ТПВ до реальної вологості, 3 якою ТПВ потрапляють до сміттєспалювального заводу $(52 \ldots 75 \%)$, знижує їх теплотворну здатність на $\sim 50 \%$. Автогоріння ТПВ такої вологості неможливо і потребує обов'язкового використання «підсвічування» додатковим висококалорійним паливом, або попереднього підсушування.

3. На сміттєспалювальному заводі «Енергія» доцільно організувати процес зменшення вмісту вологи у ТПВ з використанням дренажу, а також підсушування ТПВ перед подачею до котла, з використанням зокрема теплоти димових газів, тощо.

4. Для скорочення використання додаткового палива при спалюванні ТПВ, та підвищення ефективності використання енергетичного потенціалу ТПВ, необхідно проводити спалювання ТПВ з меншим вмістом вологи.

Найбільш ефективним способом зниження вологості ТПВ $\epsilon$ оптимізація організації процесу на стадії збирання відходів. Згідно до європейської практики, ТПВ збираються в закриті контейнери, які розташовані під навісами, задля запобігання потрапляння опадів до ТПВ. За можливістю, подібну практику доцільно впровадити в місті Києві.

\section{ЛІТЕРАТУРА}

1. Електронний ресурс - Режим доступу: http:// www.ipcc-nggip.iges.or.jp/public/gp/bgp/5_3_Waste_
Incineration.pdf

2. Павлюк Н.Ю., Сігал О.І. Підходи до проблеми поводження з твердими побутовими відходами в світі та в Україні / Промышленная теплотехника. - 2015. - №3. C.74-81.

3. Санитарная очистка и уборка населенных мест: Справочник / А.Н.Мирний, Н.Ф. Абрамов, Д.Н. Беньямовский и др.; Под ред. А.Н. Мирного. - 2-е изд., перераб. и доп. - М.: Стройиздат, 1990. - 413 с.

4. Castrillion L., Fernandez-Nava Y., Gonzalez A., Maranon E. A case study of the characteristics of municipal solid waste in Asturias (Spain): influence of season and source // Waste Manag. Res. - 2013. - №31. - P.428.

5. Тугов А.Н. Исследование процессов и технологий энергетической утилизации бытовых отходов для разработки отечественной ТЭС на ТБО: автореф. дис. ... д-ра техн. наук / OАО «ВТИ». - М., 2012. - 42 с.

6. Електронний ресурс - Режим доступу: http:// randd.defra.gov.uk/Document.aspx? Document $=11918$ W R 1910 EnergyrecoveryforresidualwasteAcarbonbasedmodellingapporach.pdf

7. http://www.worldbank.org/urban/solid_wm/erm/ CWG\%20folder/Incineration-DMG.pdf

8. Електронний ресурс - Режим доступу: https:// www.iswa.org/index.php?eID=tx...download

9. Полимерныле отходы в коммунальном хозяйстве города: Уч. пособие / Коллектив авторов. - Харьков: ХНАГХ, 2004. $-375 \mathrm{c}$.

10. Рижков С.С., Маркіна Л.М., Лісова А.В. Тверді побутові відходи як сировина для двостадійного процесу термічної деструкції / Збірник наукових праць НУК 2011- №3 - C. 140-148.

11. Ильиных Г.В. Использование результатов опреде- 
ления морфологического состава твердых бытовых отходов для обоснования системы обращения с отходами / Вестник ПНИПУ. Урбанистика. - 2012. - №1 - С.35-42.

12. Ильиных Г.В. Оценка теплотехнических свойств твердых бытовых отходов исходя из их морфологического состава / Вестник ПНИПУ. Урбанистика. - 2013.
- №3. - C.125-136.

13. Серикбаев Н.С., Махамбетова А.К., Жакупаева C.T. Элементарный состав и низшая теплота сгорания ТБО г. Астана и продуктов его переработки методом пиролиза - Вестник ЕНУ им. Л.Н. Гумилева, 2013, №6 C.228-232.

\section{A RESEARCH ON THE AMOUNT OF HEAT PRODUCED DURING COMBUSTION OF MIXED MUNICIAPL SOLID WASTE IN KIEV CITY}

Sigal O. ${ }^{1}$, Krikun S. ${ }^{2}$, Pavliuk N. ${ }^{1}$, Satin I. ${ }^{3}$, Plashykhin S. ${ }^{1}$, Kirzhner D. ${ }^{1}$, Semeniuk M. ${ }^{1}$, Kamenkov H. ${ }^{1}$

${ }^{1}$ Institute of Engineering Thermophysics of the National Academy of Sciences of Ukraine, 2a, Zhelyabova str., Kyiv, 03680, Ukraine

2 "Energy" plant of PJSC "Kyivevergo", 46, Collectorna str., Kyiv, 02000, Ukraine

3 State Enterprise "Scientific Research and Design and Technology Institute of Municipal Economy", Metropolitan Vasil Lypkivskyi St., building number 35, 03035, Kyiv, Ukraine

The calorific value of the municipal solid waste in different countries was calculated on the basis of elementary composition of the municipal solid waste.

The results of the experimental research on the amount of heat produced during the combustion of mixed municipal solid waste in Kiev city are given.

The results of the research were used at the "Energy" plant of PJSC "Kyivenergo".

References 13, tables 5, figures 4.

Key words: municipal solid waste, municipal solid waste combustion, lower calorific capacity, heat amount, humidity.

1. Electronic source. accessed: http://www.ipcc-nggip. iges.or.jp/public/gp/bgp/5_3_Waste_Incineration.pdf

2. Pavliuk N., Sigal $\bar{O}$. Approaches to the problem of treating municipal solid waste in Ukraine and in the world / Industrial heat power engineering. 2015, №3, p. 74-81.

3. The sanitation and clearing of populated areas: a handbook/ Myrnyj, A., Abramov N., Benyamovskij et., 2nd editio under the reduction of Myrnyj, A.: Strojizdat, 1990. $413 \mathrm{p}$.

4. Castrillion L., Fernandez-Nava Y., Gonzalez A., Maranon E. A case study of the characteristics of municipal solid waste in Asturias (Spain): influence of season and source . Waste Manag. Res. 2013. №31, P. 428.

5. Tugov, A. A research on the processes and technologies of energetic utilization of municipal solid waste for the development of domestic thermal power station based on the municipal solid waste: abstract of doctoral dissertation / OJSC «VTI». M., 2012, p. 42.

6. Electronic source - accessed: http://randd.defra.gov. uk/Document.aspx?Document=11918_WR1910Energyre coveryforresidualwaste-Acarbonbasedmodellingapporach. pdf

7. Electronic source - accessed: http://www.worldbank. org/urban/solid_wm/erm/CWG\%20folder/IncinerationDMG.pdf

8. Electronic source - accessed: https://www.iswa.org/ index.php?eID=tx...download

9. Polymer waste in the municipal services of the city: a tutorial/collective authors. Kharkiv, Kharkiv National Academy of Municipal Economy, 2004, 375 p.

10. Ryzkov S., Markina L., Lisova A. Municipal solid waste as a raw material for a two-phase process of thermal destruction. A collection of scientific works of Admiral Makarov National University of Shipbuilding. 2011, №3, p. 140-148.

11. Ilinych $G$. The usage of the results of the municipal solid waste morphological composition findings for waste treatment system's justification. Vestnik of State National Research Polytechnical University of Perm. Urban studies. 2013, №3, p. 125-136.

12. Ilinych $G$. Use of the results of the solid domestic waste morphological composition determination for the justification of the waste management system. Newsletter of PNIPU. Urbanistika. 2012. №1, p.35-42.

13. Serikbajev N., Mahambetova A., Zakupajeva, S. Elementary composition and lower heat capacity of municipal solid waste and its recycling products by using pyrolysis method in Astana. Vestnik L.N. Gumilyov Eurasian National University, 2013, №6, p.228-232. (Rus)

Получено 14.03.2017 Received 14.03.2017 